\title{
$\begin{array}{lllllllll}\mathrm{I} & \mathrm{N} & \mathrm{S} & \mathrm{T} & \mathrm{I} & \mathrm{T} & \mathrm{U} & \mathrm{T} & \mathrm{E}\end{array}$
}

\section{Southeastern Kentuckians Remain Optimistic Through Great Recession Growing Concerns about Sprawl, Housing, and Recreational Opportunities}

JESSICA D. ULRICH

$\mathrm{T}$ The Great Recession has hurt the economic well-being of individuals, families, and communities across America. As a result of the recession, more than one-half of the U.S. labor force ( 55 percent) has "suffered a spell of unemployment, a cut in pay, a reduction in hours or have become involuntary part-time workers."' The Great Recession is also taking its toll on chronically poor rural places like southeastern Kentucky. Using data from the Community and Environment in Rural America (CERA) surveys ${ }^{2}$ conducted in eastern Kentucky in 2007 and 2011 (see Figure 1 for the location), this brief investigates how perceptions of socioeconomic and environmental issues in one economically vulnerable rural region have changed during the recession. In 2007, the Carsey Institute conducted the first CERA survey in Harlan and Letcher counties, just months before the beginning of the recession, which officially lasted from December 2007 to June 2009. ${ }^{3}$ In 2011, Carsey researchers returned to the same counties for a second survey. Although the recession has officially ended, communities across America are still struggling to recover from its effects. ${ }^{4}$ As a chronically poor rural place, how southeastern Kentuckians are experiencing the recession may differ from other rural places with stronger socioeconomic and civic institutions. ${ }^{5}$

The surveys reveal that the recession has exacerbated concern about many community-level problems including poverty, affordable housing, sprawl, and a lack of recreational opportunities. Southeastern Kentuckians ${ }^{6}$ views regarding how environmental resources should be used have also changed. As the demand for jobs has increased, Harlan and Letcher county residents are more likely to believe that natural resources should be used for economic development rather than conserved for the future. They are also less supportive of environmental regulations such as zoning laws

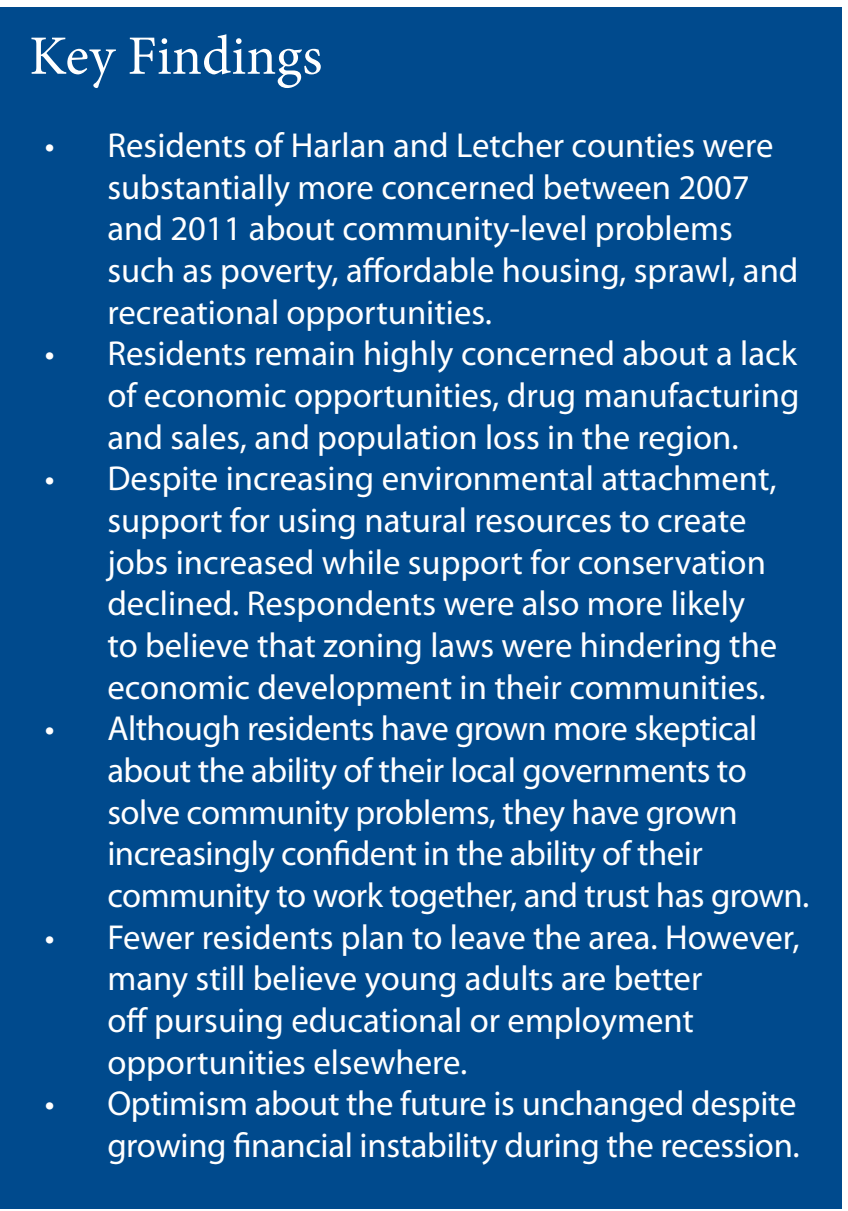

UNIVERSITY of NEW HAMPSHIRE 
Figure 1. Harlan and Letcher Counties, Kentucky

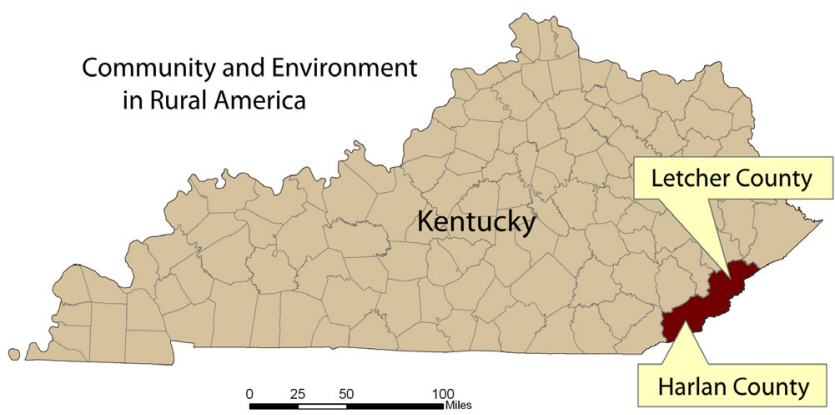

that might impede the development of their community during these tough financial times. Although residents have grown more skeptical about their local governments' ability to solve problems, they have grown increasingly confident in the ability of their community to work together, and they have more trust in one another. The region has been losing population for decades; however, the surveys indicate that fewer plan to leave the area in the near future. A greater percentage of southeastern Kentuckians think they are worse off financially than in 2007. Finally, environmental attachment appears to be growing stronger as residents of Harlan and Letcher counties are increasingly citing environment-related factors among important reasons to stay in their community.

\section{CERA Kentucky Surveys}

Since 2007, the CERA survey has been tracking rural Americans' perceptions on a wide variety of socioeconomic and environmental issues. Almost 19,000 rural Americans from diverse places encompassing forty three counties and fourteen states have participated in the CERA survey. In May and June of 2007, Carsey Institute researchers surveyed 1,000 randomly selected respondents from Kentucky's Harlan and Letcher counties, and between November 2010 and January 2011, they returned to survey 1,020 different randomly selected respondents from the same counties. These two Kentucky counties provide a snapshot of perceptions of community and environmental change in a chronically poor rural place. $^{7}$

Respondents answered approximately one hundred questions about general demographic information and their opinions on a wide variety of socioeconomic and environmental issues. Questions in both surveys were similar, but not identical. Researchers conducted the surveys over the phone. This brief focuses on the questions asked in both surveys to identify area wide (Harlan and Letcher counties combined) changes since the recession. Respondents to both the 2007 and 2011 surveys differed little on socioeconomic indicators (see Table 1).
Table 1. Demographic Characteristics of CERA RESPONDENTS IN 2007 AND 2011

\begin{tabular}{lcc}
\hline & $\mathbf{2 0 0 7}$ & $\mathbf{2 0 1 0 - 2 0 1 1}$ \\
Total number of respondents & 1,000 & 1,020 \\
Sex (percentage female) & $52.9 \%$ & $51.7 \%$ \\
Age (mean years) & 45.6 & 45.8 \\
Race (percentage non-Hispanic white) & $96.8 \%$ & $96.7 \%$ \\
Marital Status (percentage married) & $63.9 \%$ & $56.8 \%$ \\
Education (percentage over age 25 with bachelor's degree) & $17.7 \%$ & $20.5 \%$ \\
Income (percentage earning less than \$20,000 annually) & $28 \%$ & $24.2 \%$ \\
\hline
\end{tabular}

Note: All percentages are calculated using weights based on census age, race, and sex estimates. There are no significant differences by year.

\section{Overview of Harlan and Letcher Counties}

Harlan and Letcher counties are located in the heart of Appalachian coal country. These adjacent counties are several hours by car from any major metropolitan area, and they both lack a single large population center. The overwhelming majority (97.1 percent) of the population in both counties is non-Hispanic white. As one of the poorest regions in rural America, both counties are characterized by persistently high poverty levels, low median incomes, low education levels, and high unemployment rates (see Table 2). Religion plays an important role in southeastern Kentucky communities. In Harlan and Letcher counties, 25 percent attend church more than once a week, and only 16 percent never attend church (in other CERA surveys, the shares are 12 and 27 percent, respectively). ${ }^{8}$

TABLE 2. SOCIOECONOMIC AND DEMOgRAPHIC INDICATORS FOR Harlan AND LeTcher Counties, Kentucky

\begin{tabular}{lcc}
\hline & Harlan & Letcher \\
Total number of respondents & 900 & 1,120 \\
Dominant economy & Mining & Mining \\
2010 population & 29,278 & 24,519 \\
Population change 1990-2010 & $-24.9 \%$ & -10.1 \\
Percentage non-Hispanic white (2010) & $95.7 \%$ & $98.4 \%$ \\
Percentage over age 25 with bachelor's degree (2000) & $8.9 \%$ & $7.7 \%$ \\
Median household income (2009) & $\$ 26,356$ & $\$ 29,835$ \\
Unemployment rate January 2010 (not seasonally adjusted) & 12.8 & 12.4 \\
Percentage of individuals in poverty (2009) & $33.4 \%$ & $30.6 \%$ \\
Percentage of children aged 0 to 17 in poverty (2009) & $44.2 \%$ & $36.5 \%$ \\
\hline
\end{tabular}

Sources: 1990, 2000, 2010 Census decennial data, USDA Economic Research Service; American Community Survey; Bureau of Labor Statistics, U.S. Census Small Area Income \& Poverty Estimates. 
The region has been dominated by the coal and timber industries since the late nineteenth century. ${ }^{9}$ The USDA Economic Research Service labels both counties as still mining dependent, although the lower-paying service industry has made inroads. ${ }^{10}$ In recent decades, the timber industry has also become less important to the area's economy. As the largest private employer in the region, 16 percent of jobs were in mining in $2007 .{ }^{11}$ When the coal industry was booming in the 1940s, the populations of both counties peaked (Harlan had more than 75,000 residents and Letcher more than 40,000). However, when the coalfields were mechanized in the 1950s, populations declined and unemployment grew. ${ }^{12}$ In 1985 there were 900 underground mines in Eastern Kentucky, while in 2009 only 186 of these mines were still in operation. ${ }^{13}$ Although the population grew slightly in the $1980 \mathrm{~s},{ }^{14}$ population loss and unemployment continue to be issues in both counties. Since 1990, southeastern Kentucky has lost nearly 18 percent of its population.

\section{The Effects of the Great Recession on Kentucky}

The Great Recession has hit Kentucky harder than other recent economic recessions (in 1981, 1990, and 2001), and it is also taking longer for the state to recover. ${ }^{15}$ The state unemployment rate grew from 5.6 percent in June 2007 to 11.4 percent in January 2011. ${ }^{16}$ The national unemployment rate in 2007 was almost 5 percent and, in 2011, it doubled to nearly 10 percent. ${ }^{17}$ With growth in its working-age population, Kentucky emerged from the Great Recession with 88,000 fewer jobs. ${ }^{18}$ The percentage of Kentuckians who live in poverty has also increased since the recession. Prior to the recession in 2006, 17 percent were living below the poverty line compared with 13.3 percent of all Americans. In 2009, the poverty rate was 18.4 percent in Kentucky and 14.3 percent nationally. Kentucky's poverty rate was the third highest in the nation. ${ }^{19}$ The percentage of children in poverty also increased during the recession from 23.1 percent in 2006 to 25.3 percent in 2009 . Child poverty rates were higher in Kentucky than in the United States as a whole in both 2006 and 2009 (18.3 percent and 20 percent, respectively). ${ }^{20}$ Growing unemployment rates and poverty levels have increased eligibility and demand for public programs and services, putting additional stress on already constrained budgets of federal, state, and local governments. ${ }^{21}$

Although facing similar general issues, Harlan and Letcher counties are different in many ways than the state of Kentucky as a whole. The recession has taken a toll on both counties, with the unemployment rate, poverty levels, and child poverty levels in both counties growing and remaining higher than state and national levels. The unemployment rate grew from an average of 8.8 percent in the two counties in June 2007 to 12.6 in January 2011. ${ }^{22}$ In 2006, the poverty rate for the two counties was 29.9 percent, while in 2009, it was 32.3 percent. ${ }^{23}$ The child poverty rate also jumped from an already high 39.5 percent to 40.4 percent. ${ }^{24}$ Although these statistics provide a general framework of how the recession has affected Harlan and Letcher counties, CERA survey data can reveal how the recession is affecting the everyday lives of southeastern Kentuckians.

\section{Perceived Community-Level Problems in Southeastern Kentucky}

In terms of relative importance of community problems, there has been little change in Kentucky since 2007 (see Figure 2). The most important problems perceived by residents of Harlan and Letcher counties in both 2007 and 2011 were the manufacturing or sale of illegal drugs, followed closely by a lack of job opportunities. Nine out of ten survey respondents in both 2007 and 2011 indicated that these were important problems facing their communities. Although general abuse of drugs and alcohol is a problem, prescription drug abuse is particularly acute in rural areas of Eastern Kentucky, including the study region. As part of a nationwide epidemic, Kentucky led the country in the use of prescription drugs for nonmedical purposes in $2009 .{ }^{25}$

Figure 2. Perceived Problems Faced by Community TODAY BY YEAR (SIGNIFICANT DIFFERENCES FROM 2007 TO 2011 IN ITALIC FONT)

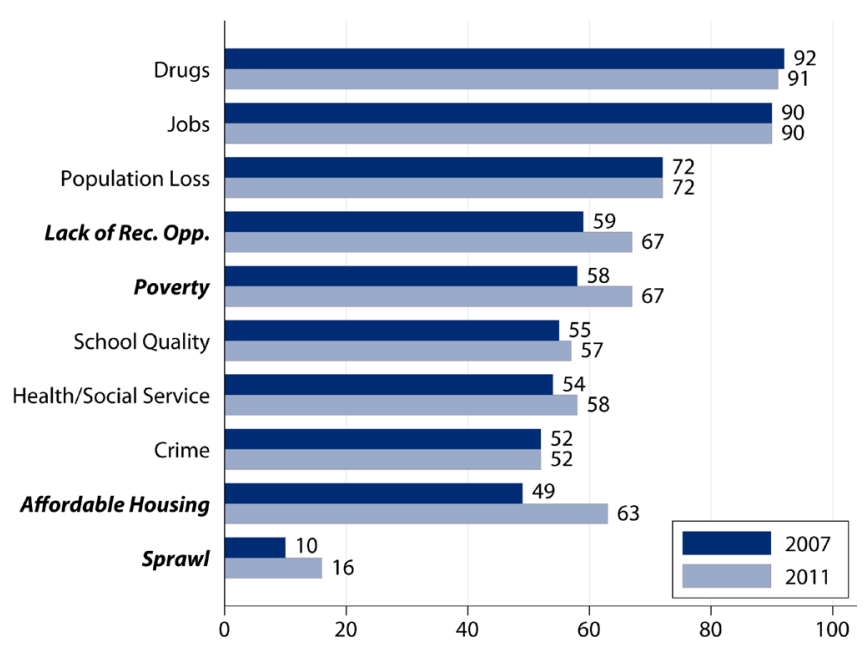


The perceived lack of job opportunities is tied to the high unemployment rate in Kentucky, which was already higher than the national average before the recession, and has become only worse since the onset of the recession. Concern about too-rapid development, growth, or sprawl ranked lowest in both 2007 and 2011. Lack of concern about development and sprawl reflects the relative lack of economic development in the area.

The most significant change from 2007 to 2011 was in the percentage of respondents saying they thought a lack of affordable housing was an important problem facing their community. In 2011, 63 percent of respondents thought lack of affordable housing was an important issue, up 14 percentage points from 2007. Although only about 30 percent of area residents are renters, one explanation for the sharp rise might be that the fair market rent for a two-bedroom apartment rose 13.5 percent in both Harlan and Letcher counties between 2007 and 2011. ${ }^{26}$ Also notable, the percentage of Kentuckians who perceived poverty or homelessness to be a problem grew from 58 percent in 2007 to 67 percent in 2011. This increase likely reflects the jump in actual poverty rates in these counties. Other significant increases were in the perceptions of too rapid development or sprawl and lack of recreational opportunities. It is unclear why there has been an increase in concern about these two issues.

\section{Environmental Concerns}

Broad concerns about environmental issues changed little between 2007 and 2011. Perceptions about the effects of conversion of farmland to other uses, loss of forestry jobs or income, global warming or climate change, and urban sprawl or rapid development of the countryside registered only small changes (not shown in figures). Respondents' perceptions about conservation and restrictions on development, however, did change significantly (see Figure 3 ). While 17 percent of respondents in 2007 thought that conservation rules that restrict development were bad thing for their community, almost twice as many (33 percent) said the same in 2007. This finding suggests that increasing numbers of Harlan and Letcher county residents would prefer to relax environmental regulations in order to promote economic development in their communities.

When residents were asked in 2007 about whether they would prefer to conserve or use natural resources, 37 percent favored using natural resources to create jobs. In 2011, amid the lingering effects of the recession, 52 percent favored using natural resources to create jobs. Given that the number of available jobs in Kentucky is still far below demand, that southeastern Kentuckians would rather use their natural resources to create jobs instead of conserve them makes sense. In tough economic times, and especially a decline in the coal industry, it becomes more difficult to justify conservation of resources over creating jobs.
Figure 3. Attitudes Towards Resource Use By YeAr (SIGNIFICANT DIFFERENCES FROM 2007 TO 2011 IN ITALIC FONT)

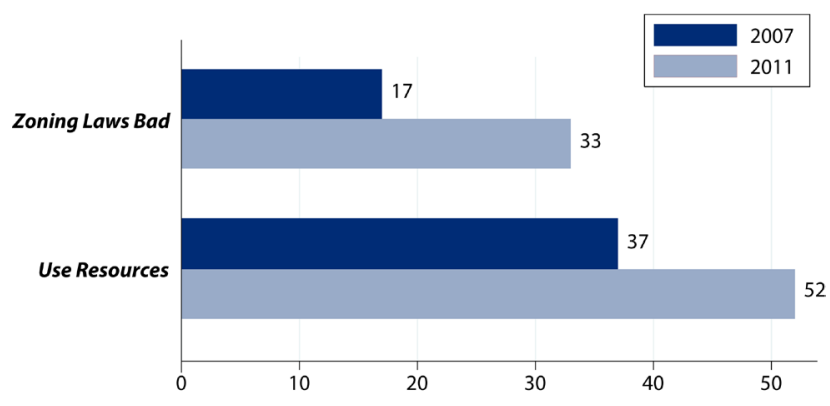

\section{Community Cohesion and Confidence in Local Government in Coal Country}

The recession also appears to have increased community cohesion but lowered confidence in local government (see Figure 4). Significantly, more respondents in 2011 said they thought their community could work together to solve local problems. Perhaps tough economic times make it particularly important for communities to work together to solve pressing problems. Alternatively, community groups may be escalating their efforts to address crucial issues that they believe the local government is incapable of ameliorating. Opinions about neighbors being helpful and trustworthy changed little between 2007 and 2011.

Figure 4. Community Cohesion AND CoNFidence in LOCAL GOVERNMENT BY YEAR (SIGNIFICANT DIFFERENCES FROM 2007 TO 2011 IN ITALIC FONT)

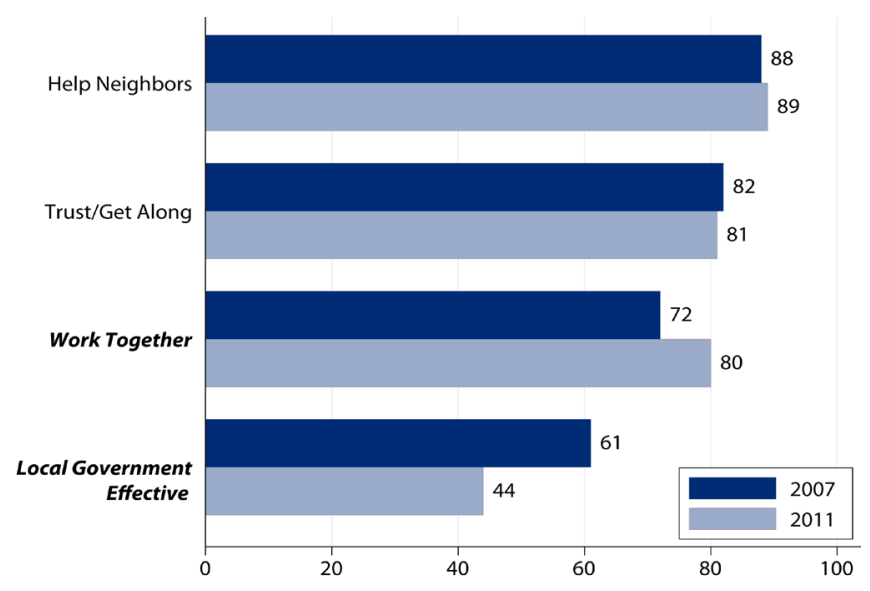

Conversely, confidence in the local government dropped dramatically. While 61 percent thought the local government was effective at solving local problems in 2007, only 44 percent said the same in 2011. Indeed, local government may not be provid- 
ing the amount of support that residents of Harlan and Letcher counties believe they need during these tough economic times. Local government, however, may not be receiving the same amount of support from state and federal governments as they did in the past, which is hampering their ability to effectively deal with local issues. In addition, problems may be growing at such a rate that it is impossible for the local government, with its current resources, to help fight the growing and persistently high poverty rates and unemployment.

\section{Outlooks on the Future and Migration}

General optimism about the future of their communities has not changed substantially over the past three years (not shown in the charts). However, residents of Harlan and Letcher counties are more likely to say they are worse off financially (see Figure 5). In 2007, 26 percent said they were worse off financially than five years prior, while in 2011, 35 percent said the same. This indicates that the recession has taken a toll on the well-being of Southeastern Kentuckians in a very direct way.

Figure 5. OUtlook On the Future and Migration Plans By Year (SIgNificant differences from 2007 TO 2011 IN ITALIC FONT)

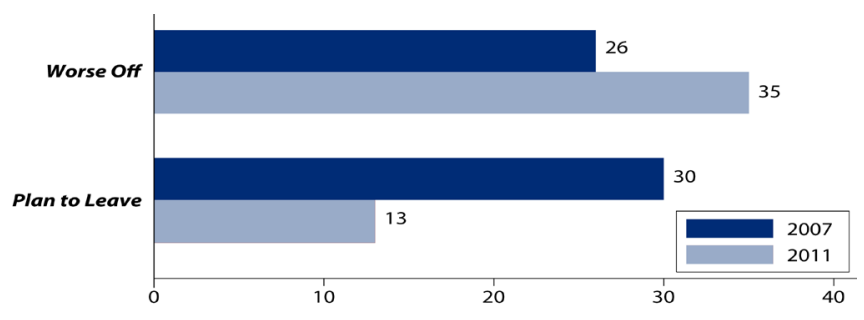

Despite economic hardship, fewer residents are planning to leave their communities today. In 2007, 29 percent said they planned to leave within the next five years. However, in 2011, only 13 percent said the same. As economic conditions worsen, it may be less feasible economically to move. Further, the bleak job market across Kentucky and the rest of the U.S. might not look any more promising than the alternatives in Harlan and Letcher counties.

The share who would advise teens to seek opportunities elsewhere remained high over the study period (not shown in figures). About 73 percent of all respondents would advise a teen to move elsewhere for educational or employment opportunities. That this percentage did not decrease significantly indicates that, although many adults do not currently think it is feasible to move themselves, they still think it is best that their children pursue opportunities elsewhere.

\section{Reasons to Stay}

From 2007 to 2011, the reasons residents wanted to stay in their communities changed little (see Figure 6). In 2011, significantly more southeastern Kentuckians said natural beauty was a very important reason to stay. Fewer respondents also said that outdoor or recreational opportunities were not an important reason to stay. These two findings indicate that at least one dimension of community attachment-the environmental connection-is growing stronger. Despite growing dislike of environmental regulations (see Figure 3), southeastern Kentuckians increasingly consider the aesthetic attributes of the natural environment important, and more specifically, an important reason to remain in their community. Opinions about other reasons to stay did not change substantially.

Figure 6. REASONS TO STAY IN COMMUNity IN 2007 AND 2011 BY YEAR (PERCENTAGE WHO SAY THE REASON IS VERY IMPORTANT; SIGNIFICANT DIFFERENCES FROM 2007 TO 2011 IN ITALIC FONT)

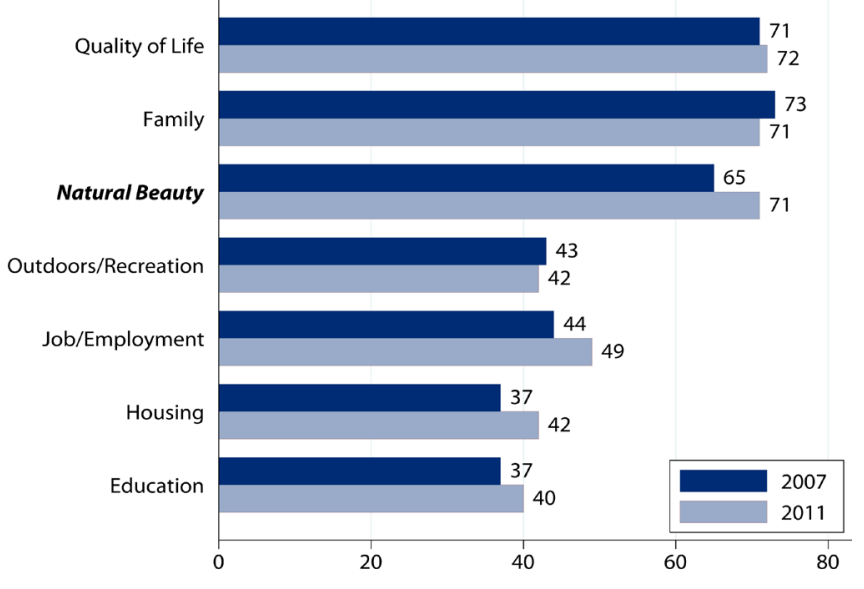

\section{Harlan and Letcher Counties Post-Recession}

This brief has illustrated how the Great Recession has affected residents of Harlan and Letcher counties in Kentucky in both objective and subjective ways. Southeastern Kentuckians are increasingly concerned about a variety of community-level and environmental problems, particularly growing poverty and the lack of affordable housing. Even though the recession officially ended in 2009 , more residents are concerned about community-level problems today (2011) than prior to the recession in 2007. Concern about every problem increased 
(or decreased insignificantly), indicating that residents of this chronically poor region see more negative effects in their communities as a result of the Great Recession.

The CERA surveys also indicate how attitudes toward the natural environment have changed since the recession began. In tough economic times, Kentuckians are more likely to support the use of natural resources to create jobs rather than conserve them for future generations. In addition, more residents think zoning laws impede the economic development of their communities. Yet, at the same time, more southeastern Kentuckians say that the natural environment is an important reason to stay in the area. Past economic development practices such as mountain-top and surface mining left visible scars on the landscape and had large-scale effects on land cover, particularly forest loss. ${ }^{27}$ Future economic development, then, should perhaps be more environmentally conscious to maintain community support.

As local, state, and federal government program budgets are cut, and poverty and unemployment rates rise, southeastern Kentuckians will need to increasingly rely on the support of other community members. Confidence in local government has declined while perceptions of community cohesiveness have increased. To weather these tough times, residents and community leaders should tap into the strengths that they see in their communities. In addition, despite losing population for decades, fewer southeastern Kentuckians now plan to leave the area to pursue opportunities elsewhere, which could help bolster community solidarity. Finally, although they are facing tough economic times, their optimism about the future has not decreased. If communities keep faith that they can work together to solve pressing problems and obtain the social, human, and economic resources that they desperately need, then perhaps Harlan and Letcher counties can begin to escape from the persistent poverty that has been plaguing them for decades.

\section{E N D N O T ES}

1. PEW Research Center, "The Great Recession at 30 Months” (Washington, DC: PEW Research Center, 2010).

2. For more information on the CERA surveys, see http:// www.carseyinstitute.unh.edu/CERA/cera-home.html.

3. The National Bureau of Economic Research, "Last Four Recessions and their Durations" (Cambridge, MA; The National Bureau of Economic Research, 2011).

4. Kentucky Center for Economic Policy, "Kentucky's Economy a Long Way from Full Recovery” (Berea, KY: Kentucky Center for Economic Policy, 2011).

5. See Cynthia M. Duncan, Worlds Apart: Why Poverty Persists in Rural America (New Haven, CT: Yale University Press, 1999).

6. Throughout the brief, "southeastern Kentuckians" refers to residents from Harlan and Letcher counties.

7. Along with chronically poor areas, Carsey researchers have identified three other types of rural places: amenityrich, declining resource-dependent, and amenity-transition. See L. C. Hamilton et al., Place Matters: Challenges and Opportunities in Four Rural America. A Carsey Institute Report on Rural America (Durham, NH: Carsey Institute, University of New Hampshire, 2008).

8. All percentages based on CERA data are calculated using weights based on recent census age, race, and sex estimates.

9. Duncan, Worlds Apart.

10. U.S. Department of Agriculture, Economic Research Service, “2004 County Typology Codes” (Washington, DC: USDA).

11. Joel Harter and Chris Colocousis, "Environmental, Economic and Social Changes in Rural America Visible in Survey Data and Satellite Images," Issue Brief No. 23 (Durham, NH: Carsey Institute, 2011).

\section{Ibid.}

13. Kentucky Office of Energy Policy, Division of Fossil Fuels and Utility Services and the Kentucky Coal Association, "Kentucky Coal Facts" (Lexington, KY: Kentucky Department for Energy Development and Independence, 2011).

14. See Kenneth M. Johnson and Calvin L. Beale, “The Rural Rebound,"Wilson Quarterly, vol. 22, no. 2 (1998): 16-27.

15. Kentucky Center for Economic Policy, "Kentucky's Economy a Long Way from Full Recovery."

16. Kat Downs, Mary Kate Cannistra, and Nathanial Vaughn Kelso, "Interactive Map: Unemployment Rate by County," The Washington Post, 2011. Available at www.washingtonpost. com/wp-srv/special/nation/unemployment-by-county/).

17. Ibid. 
18. Kentucky Center for Economic Policy, "Kentucky's Economy a Long Way from Full Recovery."

19. U.S. Census Bureau, Model-based Small Area Income and Poverty Estimates (SAIPE) for School Districts, Counties, and States 2006 and 2009 (Washington, DC: U.S. Census Bureau, 2009).

20. Ibid.

21. Kentucky Center for Economic Policy, "Kentucky's Economy a Long Way from Full Recovery."

22. Downs, Cannistra, and Kelso, "Interactive Map: Unemployment Rate by County."

23. U.S. Census Bureau, "Model-based Small Area Income and Poverty Estimates (SAIPE)."

24. Ibid.

25. Mark Potter, "Prescription Drug Abuse Ravages a State's Youth,” MSNBC News, July 6, 2009.

26. National Low Income Housing Coalition, "Out of Reach 2007 and 2011" (Washington, DC: National Low Income Housing Coalition, 2011).

27. Harter and Colocousis, "Environmental, Economic and Social Changes."

\section{A C K N O W L E D G M E N T S}

The author would like to thank Mil Duncan, Chris Colocousis, Larry Hamilton, Curt Grimm, Amy Sterndale, Laurel Lloyd, Dee Davis, and Barbara Ray at Hiredpen for their assistance on this brief.
ABOUT THE AUTHOR
Jessica D. Ulrich is a doctoral student in the Department of Sociology at the University of New Hampshire and a research assistant at the Carsey Institute (jessicad.ulrich@ gmail.com). 


\section{$\triangle$ UNIVERSITY - of NEW HAMPSHIRE}

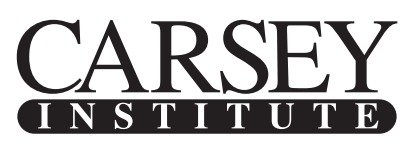

Building knowledge for families and communities

The Carsey Institute conducts policy research on vulnerable children, youth, and families and on sustainable community development. We give policy makers and practitioners timely, independent resources to effect change in their communities.

This work was supported by the Ford Foundation and the W. K. Kellogg Foundation.

Huddleston Hall

73 Main Street

Durham, NH 03824

(603) $862-2821$

www.carseyinstitute.unh.edu 